\title{
Economic Instruments to Fund Solid Waste Management Services: Analysis and Recommendations for Jordan
}

\author{
Veronika Alhanaqtah \\ College of Business, Tafila Technical University, PO box 66110, Tafila, Jordan \\ * E-mail of the corresponding author: ver-grabko@yandex.ru
}

\begin{abstract}
The goal of this paper is to analyze different types of economic instruments as ways to improve financial sustainability of the solid waste management sector. Through a review of various instruments applied in the world practice this paper intends to encourage the gradual implementation of economic instruments in the solid waste sector of Jordan. The problem analysis of waste management sector shows that Jordan is still unable to properly tackle the problem of waste and makes initial steps to adhere to either national or international standards for environmental protection. Current legislation in the solid waste management sector addresses the waste issues but in generic manner. It indicates responsible agencies, fees for the collection of solid waste and fines in case of noncompliance. The laws relate mainly to the solid waste disposal and landfilling at the expenses of other practices. Thus, it appears that a number of principles are not incorporated in the Jordanian regulatory framework. Ideally, economic instruments should be implemented harmoniously throughout the whole region. However, environmental progress could be significantly delayed if to wait for a comprehensive unified approach. Building on what already exists should have first priority. Each municipality may need to choose those economic instruments that have potential for their own situation. In time, the most cost-effective instruments will become evident and widespread. A set of revenue-generating, revenue-providing and non-revenue instruments is recommended to be given priority for Jordan.
\end{abstract}

Keywords: municipal solid waste, deposit-refund, tax, product take-back, extended producer responsibility, feedin tariff for waste-to-energy generation

DOI: $10.7176 / \mathrm{JESD} / 10-14-16$

Publication date:July $31^{\text {st }} 2020$

\section{Introduction}

There is a large body of instruments to fund solid waste management (SWM) services. Commonly, they complement existing regulatory requirements for the waste sector and should not be seen as a replacement for an appropriate regulatory framework. Although each instrument refers to different sector needs, jointly they have the following objectives: to reduce generation of waste, increase recyclability and content of recyclables, reduce hazardous waste rate, stimulate the market demand for products that are more recyclable, stimulate the private sector investment and participation in the solid waste sector, promote cost-effective service delivery and generate revenues to cover costs for solid waste services (Global 2003).

Economic instruments have become the matter of scientific interest in developed countries since the 1980s. The experience of their implementation has shown that they may be highly effective in achieving environmental targets such as reducing the rate of waste generation, diverting waste from disposal to recycling. Noteworthy, adequate enforcement mechanisms should be in place (Forum 2002; United Nations 2005; European 2013).

There has also been growing interest to apply economic instruments in waste sector in developing countries. It appeared that they have some beneficial advantages compared to the command-and-control regulation (Global 2003; Pearce \& Turner 1994; Bell \& Russell 2002; Scharff 2014). These advantages are cost effectiveness, economic efficiency, incentives for innovation, the potential for revenue generation. Revenues can be used in various ways such for instance as to improve waste management services or to reduce distortionary taxes elsewhere in the economy, generating a "double dividend" (A framework 2006).

However, implementation of economic instruments implies high administrative demands (Global 2003) and requires the compliance of certain pre-conditions like adequate institutional framework in terms of acquiring appropriate information, monitoring compliance and illegal activities, enforcement (United 2005) and political will (Note 1). Mentioned pre-conditions are hardly affordable in many developing countries (Bell \& Russell 2002; Russell \& Vaughan 2003). Therefore, command-and-control regulation continues to dominate environmental policy including SWM. 
Economic instruments are being applied on a random basis to the solid waste sector. No reference was found in the global literature indicating that any country had made a comprehensive effort to develop the full range of viable economic instruments in solid waste management. When viewed commonly these instruments show promise to improve solid waste management. Their application requires a specific study in each country to determine whether the capacity and legal framework exist for implementation and whether related prices would be affordable (Global 2003).

The goal of this paper is to analyze different types of economic instruments as ways to improve financial sustainability of SWM sector. Through a review of various instruments applied in the world practice, this paper intends to encourage the gradual implementation of economic instruments to fund solid waste management services in Jordan.

In the first paragraph categories of economic instruments used in the solid waste management are considered. In the second paragraph the waste management problem analysis for Jordan has been done. In the last paragraph discussion of the results and recommendations for Jordan have been made.

\section{Categories of economic instruments used in the solid waste sector}

\subsection{Categorization of instruments}

Generally economic instruments are based on the following principles:

- "polluter pays" (user pays) which charges the party responsible for generating solid waste;

- "proximity" which encourages processing, recycling, reuse or disposal of waste near the point of its production.

The literature review does not consistently classify the versatile economic instruments acceptable to environmental policy making. The most commonly applicable categories are noted in the Table 1 . While the literature represents general consent on key subcategories of economic instruments (e.g., charges, tradable permits, deposit-refunds), it is noteworthy that the references do not necessarily use the same categories to group these subcategories (Hogg et al. 2011). For the sequence, to the extent possible given that the body of literature has no single agreed categorization system. Categories that most harmonize with those in the Table 1 below are suggested for use in the solid waste sector.

Table 1. Comparison of references classifying economic instruments

\begin{tabular}{|l|l|}
\hline \multicolumn{1}{|c|}{ World Bank } & \multicolumn{1}{c|}{ UNEP } \\
\hline - fees, charges, taxes; & $\bullet$ redefining property rights; \\
- market creation (includes property rights, deposit & $\bullet$ market creation (includes tradable permits); \\
systems, tradable permits); & $\bullet$ charge and fee systems; \\
- performance rating; & • fiscal instruments (includes taxes); \\
- liability legislation (includes performance bonds); & • deposit systems (incudes performance bonds); \\
- final demand intervention (includes eco-labeling, & • financial instruments (includes subsidies, grants, \\
education, disclosure laws, blacklists/polluter & \multicolumn{1}{c|}{ soft loans, funds); } \\
ratings). & • liability (includes insurance). \\
\hline
\end{tabular}

Source: based on (Global 2003; Huber et al. 1998; Rietbergen et al. 2000)

Among them revenue generating instruments: charges, taxes and subsidy reduction. Revenue providing instruments: subsidies, grants, tax credits, host community incentives, development rights and property rights and funds. Non-revenue instruments: product and production change incentives, trade-off arrangements, deposit-refund systems, product stewardship, take-back systems, performance disclosure, liability law, performance bonds, procurement policies (Global 2003).

All the instruments have value and are not ranked. No one instrument is consistently more attractive than the others. Also, in conclusion, some will be recommended as immediately appropriate for use in developing countries such as Jordan.

We are wondering whether cost-recovery mechanisms and higher user fees or taxes can make a SWM project sustainable? What are other ways of making it sustainable? There are a number of economic instruments that can:

- $\quad$ promote green investment and innovation; 
- $\quad$ invest in better infrastructure;

- $\quad$ promote recycling;

- incentivize reduction or recycling of waste.

In this article we analyze economic instruments of SWM through three categories: product take-back, taxes and incentives in the form of feed-in tariff for waste-to-energy generation.

\subsection{Product take-back}

Product take-back includes extended producer responsibility (EPR), deposit-refund system, buy back scheme, incentives for the return of materials containing toxic and hazardous substances.

\subsubsection{Extended producer responsibility}

Extended producer responsibility means that producers are financially or physically responsible, or both, for the products they make or sell and for any associated packaging when the products become waste (Monier et al. 2014). How does EPR work? Depending on the waste type there are different EPRs:

(a) Funding. In fee-based models, producer pays an upfront fee proportional to quantity of a product in the market, funding the collection and recycling infrastructure as needed. They can set up and manage its own EPR scheme or delegate to a Producer Responsibility Organization.

(b) Collection. Packaging is collected via curbside recycling services. Clothing is collected through designated drop-off points or in-store product takeback.

(c) Treatment. Packaging is reprocessed into a secondary raw material. A product or component part can be refurbished and reused. Hazardous or hard-to-recycle products are disposed appropriately.

However, there are several conditions for successful implementation of EPR such as clear legislation about waste type, handling requirements; access to proper collection service for the products that need to be returned to the manufacturer; sufficient data quality, monitoring and control systems; and cooperation between governments, producers and waste management companies. Taking into account these conditions EPR scheme can be very advantageous (Table 2).

Table 2. Advantages of EPR

\begin{tabular}{|c|c|}
\hline Producers & $\begin{array}{l}\text { - enables producers to secure better access to secondary materials for their own supply } \\
\text { chains. }\end{array}$ \\
\hline Municipality & $\begin{array}{l}\text { - } \text { supports the achievement of recycling targets; } \\
\text { - } \quad \text { useful policy tool to work towards circular economy and zero waste; } \\
\text { - } \quad \text { enables municipality to control who buys or makes products indirectly; }\end{array}$ \\
\hline Consumer & $\begin{array}{l}\text { - shifts burden of cost associated with end-of-life products from government authorities } \\
\text { (and therefore the taxpayer) onto producers; } \\
\text { - only those consumers who buy the product end up paying for its disposal. }\end{array}$ \\
\hline Environment & $\begin{array}{l}\text { - forces producers to remain accountable for their product past its sale; } \\
\text { - provides incentives to prevent waste at the source; } \\
\text { - promotes product and packaging design for the environment; } \\
\text { - promotes sustainable consumption as recycling cost borne by the producer is internalized } \\
\text { in the price of the product. }\end{array}$ \\
\hline
\end{tabular}

Source: based on the information from the World Bank course on Solid Waste Management.

How does EPR work in practice? There are over 400 schemes in operation globally most of which are mandatory (Puig Ventosa 2019). For example, Japan requires manufacturers to use recycled materials and reusable parts in new products. In Europe, packaging, electrical and electronic goods and cars have EPR requirements. Bulgaria requires producers and importers of packaging must take back their packaging waste themselves, adhere to a collective take-back scheme and pay a packaging tax. France EPR covers furniture, tires and infectious healthcare waste. In Tunisia producers adhere to the public take-back system for plastic packaging and pay a levy on quantities placed in the market. Many US states require product stewardship for obsolete e-waste.

\subsubsection{Deposit-refund system}

Deposit-refund system is the next product take-back economic instrument that works by adding an extra charge to a product. This charge is partially or completely refunded when the product is returned. This system is commonly 
used for beverage containers, batteries, tires, automotive oil, printer cartridges, consumer electronics, shipping pallets and any product that is currently being disposed of and contains materials that can be recycled (Walls 2013). Deposit-refund system helps to avoid litter and increase collection rates of that material (Note 2). This instrument doesn't require much investment and is easy to enforce and monitor (Note 3).

\subsection{Taxes}

Taxes can help manage solid waste management costs. There are two types of taxes specifically related to SWM and commonly levied around the world: product taxes and tourism taxes.

\subsubsection{Product tax}

Product tax is levied on import and manufacture of products to reduce consumption and regulate production of certain products. Commonly taxed items include non-recyclable packaging, single-use plastic bags and cups, and products that contain less than a fixed quantity of recycled material.

Plastic bag taxes are an example of product tax. There are also numerous examples of a plastic bag policies around the world. High-income countries like Denmark, Sweden and Ireland have adopted plastic bag taxes. For example, in Ireland the plastic bag levy generated 200 million euros over 12-year period, which was used to fund environmental projects. Developing economies like South Africa, Kenya (Selection 2005) and Bangladesh have introduced plastic bag bans driven by visible plastic bag litter and limited waste collection and recycling rates. For example, before 2008 an estimated 3 billion plastic bags used daily across China creating more than 3 million tons of garbage each year. China banned sales outlets from providing free plastic bags that are less than $0.025 \mathrm{~mm}$ thick. As a result, the limit in plastic bag production saved China 1.6 million tons of petroleum, and supermarkets reduced plastic bag usage by $66 \%$.

\subsubsection{Tourism tax}

Tourism tax is a small fee charged to visitors who are staying overnight in a country or city. Funds are used to preserve the environment in tourist hotspots and to offset any damage caused by mass tourism. For example, Bali plans to introduce a $\$ 10$ tourist tax for foreign visitors to help clean up its beaches.

\subsection{Feed-in tariff for waste-to-energy generation}

Incentives represent feed-in tariff for waste-to-energy generation. This is the incentive to recover the cost (Figure $1)$.

\begin{tabular}{|l|l|l|}
\hline $\begin{array}{l}\text { A preferential tariff or a } \\
\text { guarantee of payment is } \\
\text { fixed for the sale of energy } \\
\text { from a generating station } \\
\text { using renewable energy } \\
\text { sources as opposed to using } \\
\text { conventional energy sources. }\end{array}$ & $\begin{array}{l}\text { Long-term contracts and } \\
\text { price certainty are provided } \\
\text { to attract investments in } \\
\text { renewable energy. }\end{array}$ & $\begin{array}{l}\text { Tariff is set on a project- } \\
\text { specific basis, as every } \\
\text { waste-to-energy facility is } \\
\text { unique in terms of waste fuel } \\
\text { characteristics, project } \\
\text { sizing, configuration, } \\
\text { technology and operational } \\
\text { equipment. }\end{array}$ \\
\hline
\end{tabular}

Figure 1. Feed-in tariff for waste-to-energy generation

Source: based on the information from the World Bank course on Solid Waste Management.

The example above shows how feed-in tariffs work for electricity generated from waste-to-energy facilities. Implementation of this environmental policy instrument is recommended for Jordan.

\subsection{Criteria for choosing instruments}

There are numerous of potential solid waste instruments that each country could implement. The global literature 
does not provide satisfactory comparative information to make a conclusion whether certain economic instruments are better than others. The data is not available to assess the extent to which any instrument would increase recycling, reduce waste and toxics or generate revenues. Each region and country is unique. The choice of an instrument depends on local priorities, preferences and abilities.

Selection of an adequate instrument needs to consider local and global priorities. Given that there are many instruments for the solid waste sector and each instrument involves different possible activities, governments must opt for where to start. Does one start with improving future waste disposal or with remediating past disposal sites and landfills? Is the focus on wastes from households or industries? Does one start with source reduction of waste generation or with increasing recycling after waste generation? If source reduction or recycling are chosen as priorities. Which category of waste has priority? Do the lowest cost instruments have priority over the higher cost instruments? How much does ease of implementation affect the choice?

The following evaluation criteria are recommended to be considered:

$\checkmark$ Environmental effectiveness: does the instrument lead to the desired environmental improvements, such as reduction in waste generation, increased waste recycling, reduced emissions from transport and disposal;

$\checkmark$ Economic cost-effectiveness: does the instrument create incentives for investment and innovation toward reduction of pollution control costs;

$\checkmark$ Administrative cost-effectiveness: does the instrument require affordable and available levels of skill and effort to implement and monitor;

$\checkmark$ Revenue usefulness: are revenues generated able to be applied to address the environmental objectives of the instrument and adequate to create measurable improvement;

$\checkmark \quad$ Ease of implementation and replicability: are the relative costs and benefits relatively easy to assess and the legal requirements for introducing the new instrument reasonable;

$\checkmark$ Acceptance: does the general public and the affected industries accept the instrument as a viable means of cost-effectively achieving environmental improvement without adversely affecting competitiveness, employment, income distribution and trade;

$\checkmark$ Distributional effects: is there distributional disparity or inequitability in the application or impact of the instrument, particularly regarding effects on lower income households, small businesses, and disadvantaged parties;

$\checkmark$ Short-term results: does the instrument have the potential to result in sufficient short-term improvement to motivate political administrators to undertake commitment to the costs associated with the instrument under their political term;

$\checkmark$ Economic development enhancement: does the instrument provide an environment that maintains trade competitiveness and encourages industrial development and employment generation.

$\checkmark$ Waste type applicability: does the instrument address a wide range of waste types and have significant impact on overall urban waste quantities, or does the instrument address only a limited number of unique and important waste types (Green 2017; Achillas et al. 2013).

\section{Waste management problem analysis for Jordan}

\subsection{Review of the waste problem}

Municipal solid waste management, i.e. its collection, treatment and disposal is one of the most important services provided by local authorities and cities in Jordan. The current total MSW generation in Jordan is estimated at 2.655.977 tn/yr for an approximately 7.7 million population including refugees. The municipal solid waste generation is expected to reach: $3.247 .635 \mathrm{tn} / \mathrm{yr}$ in 2019, 3.765.334 tn/yr in 2024, 4.460.963 tn/yr in 2029 and $5.247 .173 \mathrm{tn} / \mathrm{yr}$ in 2034 (Development 2014).

Organic waste (bio-waste) represents the biggest share of MSW: about $60 \%$ (Saidan 2019). With the Decision No. 11392/02, the Government of Jordan approved its first National Solid Waste Management Strategy in September 2015 (Jordan 2020). The national strategy aims at shifting over 20 years from "an old, inefficient, costly and environmentally unstable municipal solid waste management system towards a modern and integrated one that will be based on the three R's approach (Reduce, Reuse, Recycle)" (Development 2014). In particular, it seeks to reduce by $75 \%$ the amount of bio-waste landfilled in 2024 . The purpose of this action is to ensure in the coming five to seven years, the safe and sanitary disposal of municipal solid waste. The specific objectives are to (1) "consolidate the existing regulatory framework to bring it in line with the goals set in the national strategy (2) improve the transfer and disposal management system in the Central and Northern Region (3) improve the socio- 
economic well-being and health status of informal waste pickers working in dumpsites (4) raise general awareness, understanding and knowledge about the most important municipal solid waste management issues" (Development 2014).

The long-term objective involves incorporating the following principles in the regulatory framework:

- the hierarchy of integrated SWM practices (prevention, preparing for re-use, recycling, other recovery (e.g. energy recovery) and disposal);

- the extended producer responsibility principle;

- the polluter-pays principle;

- the proximity principle (the disposal or recovery of waste shall be undertaken in one of the nearest appropriate installations, by means of the most appropriate methods and technologies);

- $\quad$ the precautionary principle.

\subsection{Current problems in the solid waste management system}

As a result of the analysis of the current situation we found out the following problems in the solid waste management system in Jordan (Development 2014; Aljaradin 2013; Shatnawi 2018; Aldayyat et al. 2019). First, there is a lack of an appropriate regulatory framework in Jordan. Current legislation [The Jordanian 2006; Amended 2015; Public 2008) in the solid waste management sector addresses the waste issues but in generic manner. These laws indicate responsible agencies, fees for the collection of solid waste as well as fines in case of noncompliance. As regards secondary legislation, it relates mainly to the solid waste disposal and landfilling at the expenses of other practices. Thus, it appears that a number of principles are not incorporated in the Jordanian regulatory framework (waste prevention, 3Rs approach, EPR approach, polluter-pays principle).

Second, there is the lack of proper final disposal facilities. There are 17 official dumpsites in Jordan. They are often not properly designed and uncontrolled (Note 4); there are no particular standards or specifications for MSW management system in Jordan. Additionally, there is an absence of source separation and recycling. There is a series of special and hazardous waste streams whose handling should be separate. Thus, municipal and other types of waste generated are mainly dumped at dumpsites. Air pollution, water contamination by the leachate, odors, health risk are major issues that shouldn't be underestimated (Development 2014; Alhanaqtah 2014; Nagy \& Aljaafreh 2018).

Third, insufficient cost-recovery policies. There are no positive or negative incentives for generation of industrial waste pollutants. Given the current socio-economic content full cost recovery in accordance with the polluter-pays principle is not affordable in the short-run. Appropriate institutional infrastructure and clear guidelines are required to adopt the polluter-pays principle. Taking into account poor financial conditions of the waste sector, waste-toenergy projects are currently prioritized (Development 2014; Pakhomova et al. 2019).

Finally, there is no monitoring system for solid waste and enforcement for its use and implementation. Clear responsibilities of all concerned public authorities are not described anywhere in the legislative framework. Targets for recycling and recovery of municipal and other special waste streams as well as prohibition of bio-waste disposal in landfills are not set (Alhanaqtah 2019; Alhanaqtah et al. 2019).

\section{Discussion the results and recommendations}

Solid waste management is the one of the biggest challenges in Jordan which adversely impacts the environment, socio and economic conditions. Thus, there is the need to identify effective policy instruments to overcome this challenge and bring into life of Jordanian people sustainability principles. The problem analysis of waste management sector shows that Jordan is still unable to properly tackle the problem of waste and makes initial steps to adhere to either national or international standards for environmental protection and sustainability.

While waste management is typically a locally provided and managed services, both national and local governments play a role in defining the regulatory framework within which solid waste management services can be developed (Kling et al. 2016). Jordanian government is recommended to:

- develop laws to establish guidelines, targets, operational and environmental standards for waste management;

- provide financing and technical expertise such as by sharing costs or evaluating plans for the construction of new disposal sites, to help local governments achieve national goals;

- $\quad$ provide direct financial support for infrastructure investments;

- develop guidelines for transparent procurement of services from the private sector. 
As far as local governments, they are politically sensitive about any increase in charges or taxes unless they can refer to some national directive. They don't have the capacity to determine which instruments would be most costeffective for their use. It is preferred that the national government provides a policy guideline on charges so that local officials have a reduced political risk when implementing cost recovery. The duty of local governments should be:

- decide how physical and financial resources should be allocated and how costs can be recovered;

- introduce innovative waste programs such as the introduction of bins of different colors for household source separation or local composting programs;

- identify private sector operators to build or operate services;

- establish rules and regulations on management and disposal of waste;

- $\quad$ site new landfills or other waste facilities;

- monitor service coverage, check for citizen feedback.

For a national level we also recommend create a national commission tasked to study economic instruments for the solid waste sector and develop national policies and implementation directives to local governments. Enabling legislation to empower local governments is recommended.

All of the economic instruments discussed in this paper have merit. Ideally, economic instruments should be implemented harmoniously throughout the whole region. However, environmental progress could be significantly delayed if to wait for a comprehensive unified approach. Opportunities of stimulating change may be missed. Building on what already exists should have first priority. The following instruments are recommended to be given priority for Jordan:

$\checkmark$ Revenue-generating instruments that are user charges attached to property taxes, electricity bills or water bills would have the most positive impact. Further, a favorable climate for private sector investment and participation in service delivery would be provided. Variable rate charges are not recommended for Jordan at this time because of the administrative costs and potential adverse impact of causing illegal dumping. Additionally, taxes on products that are difficult to dispose or recycle would influence consumer choices and related production decisions.

$\checkmark$ Revenue-providing instruments, such as low-interest credit lines, tax credits, relief from customs duties, accelerated depreciation, can provide financial incentives for the private sector to invest and participate in solid waste service delivery.

$\checkmark$ Non-revenue instruments that address procurement policies for waste services are particularly important for stimulating private sector investment and participation in solid waste services. They would augment market demand for products that have significant recycled content.

$\checkmark$ Non-revenue instruments such as product take-back are desirable. All non-revenue instruments that create strong disincentives to damage the environment or adversely affect public health are recommended.

$\checkmark$ Taking into account poor financial conditions of the waste sector, waste-to-energy projects are currently prioritized.

$\checkmark \quad$ To tackle the problem of plastics we suggest to implement plastic bag taxes as an example of product tax. It could be in the form of levy which will additionally generate revenues to fund solid waste management programs. Or else to ban sales outlets from providing free plastic bags. It will result in the limit in plastic bag production and usage as well as it will save the petroleum for plastics production.

In areas where local conditions allow solid waste services can be managed on an inter-municipal scale. Intermunicipal government cooperation typically occurs through the use of shared assets for waste transfer, disposal and city cleaning. This type of coordination leads to economies of scale, exchange of technical skills, cost savings through fewer investments and better access to financial sources. Inter-municipal government cooperation is most effective when operational objectives are similar across entities. It is difficult to cooperate when municipalities have different environmental and waste management priorities.

Additionally, in choosing between instruments, it is recommended that Jordan considers the following suggestions:

$\checkmark$ New instruments should be gradually introduced. Solid waste laws have a higher chance of achieving their policy goals if they are designed and implemented in stages with progressively more stringent standards, as this allows for people involved to develop expertise and raise financial resources. Economic instruments that are complementary to existing administrative approaches should be given priority.

$\checkmark \quad$ Instruments that lead to greater use of labor and less use of energy and capital should be given priority over those that are investment and consumption intensive.

$\checkmark \quad$ Instruments that target existing environmental problems or service gaps should be given priority. 
$\checkmark$ Revenues from economic instruments implementation should be earmarked for improvement in waste management services.

$\checkmark$ Instruments that focus on long-term change in behavior should be implemented even though their results may not be immediately evident.

Finally, economic instruments can be implemented within the framework of existing national legislation. It is preferable for the government authorities to highlight the need for economic instruments and provide general targets for their study and implementation as well as to outline responsible parties. However, in every region of Jordan the conditions affecting the choice of a particular economic instrument may be different. Each municipality may need to choose those economic instruments that have potential for their own situation. In time, the most costeffective instruments will become evident and widespread.

\section{References}

A framework for considering market-based instruments to support environmental fiscal reform in South Africa (2006). Draft policy paper. [Online] Available: https://www.cbd.int/doc/meetings/im/wscbteeb-mena01/other/wscbteeb-mena-01-enviro-fiscal-reform-sa-en.pdf (July 22, 2020)

Achillas, C., Moussiopoulos, N., \& Karagiannidis, A. (2013) The use of multi-criteria decision analysis to tackle waste management problems: A literature review. Waste Management \& Research, 31, 115-129.

Aldayyat, E., Saidan, M., Abu Saleh, M., \& Linton, C. (2019). Solid waste management in Jordan: impacts and analysis. [Online] Available: https://dl.uctm.edu/journal/node/j2019-2/27 18-16 p454-462.pdf (July 22, 2020)

Alhanaqtah, O. (2014). Tragedy of the commons relative to waste disposal in Jordanian Al-Tafilah. European Science Review. 11-12, 100-102.

Alhanaqtah, V. (2019). Integrating the informal sector for improved waste management in rural communities. In: Handbook of Research on Rural Sociology and Community Mobilization for Sustainable Growth. Hershey: IGI Global, p. 208-224.

Alhanaqtah, V., Alhanaqtah, O., \& Pakhomova, A. (2019). Private sector development in waste management in rural areas. In: Handbook of Research on Rural Sociology and Community Mobilization for Sustainable Growth. Hershey: IGI Global, p. 251-270.

Aljaradin, M. (2013). Towards sustainable solid waste management in Jordan. [Online] Available: https://www.researchgate.net/publication/321300186 Towards sustainable solid waste management in Jordan (July 22, 2020)

Amended law on municipalities No. 41 of 2015. [Online] Available: https://www.iec.jo/sites/default/files/202002/2015\%20Municipalities\%20Law\%20EN\%202017-07-09.pdf (July 22, 2020

Bell, R. G. \& Russell, C. (2002). Environmental policy for developing countries. Issues in Science and Technology. 18(3), 63-70.

Development of a national strategy to improve the municipal solid waste management sector in the Hashemite Kingdom of Jordan (2014): Baseline study on the existing MSWM system in the Hashemite Kingdom of Jordan. [Online] Available: https://ec.europa.eu/neighbourhoodenlargement/sites/near/files/c $2016 \quad 6629$ jordan aap 2016 part 2 aap 2017 part 1 annex 1.pdf (July 22, $\underline{2020)}$

European Environment Agency (2013). Towards a green economy in Europe: EU environmental policy targets and objectives 2010-2050. [Online] Available: http://www.eea.europa.eu/publications/towards-a-green-economy-ineurope (July 22, 2020)

Forum for Economics and the Environment (2002). Training manual for the Forum for economics and the environment. [Online] Available: http:/www.econ4env.co.za/training/training.html.

Global review of economic instruments for solid waste management in Latin America (2003). Inter- American Development Bank. Regional policy dialogue. Washington DC. February 25-26, 2003. [Online] Available: https://publications.iadb.org/publications/english/document/Global-Review-of-Economic-Instruments-for-SolidWaste-Management-in-Latin-America.pdf (July 22, 2020)

Green Growth Indicators (2017). OECD Green Growth Studies. [Online] Available: https://www.oecd.org/environment/green-growth-indicators-2017-9789264268586-en.htm (July 22, 2020)

Hogg, D, Sherrington, C., \& Vergunst, T. (2011) A comparative study on economic instruments promoting waste 
prevention. Final report to Bruxelles environment: Eunomia Research and Consulting. [Online] Available: https://document.environnement.brussels/opac css/elecfile/Etude $\% 20$ dechets $\% 20$ Eunomia $\% 20$ Report $\% 20$ en (July 22, 2020)

Huber, R., Ruitenbeek, J., \& Seroa da Motta, R. (1998). Market based instruments for environmental policymaking in Latin America and the Caribbean: Lessons from eleven countries. World Bank discussion paper No. 381. Washington DC.

Jordan 2025. A national vision and strategy. [Online] Available: https://www.greengrowthknowledge.org/nationaldocuments/jordan-2025-national-vision-and-strategy (July 22, 2020)

Kling, M., Seyring, N., \& Tzanova ,P. (2016). Assessment of economic instruments for countries with low municipal waste management performance: An approach based on the analytical hierarchy process. Waste Management \& Research, 34(9), 912-922.

Monier, V., Hestin, M. \& Cavé, J. (2014). Development of guidance on extended producer responsibility (EPR). Final report.

[Online]

Available: https://ec.europa.eu/environment/waste/pdf/target_review/Guidance $\% 20$ on $\% 20 \mathrm{EPR} \% 20-\% 20 \mathrm{Final} \%$ 20Report.pdf (July 22, 2020)

Nagy, I. \& Aljaafreh, O. (2018). The environmental challenges, problems and management: a case study of Jordan. [Online]

Available: https://www.researchgate.net/publication/328927588 THE ENVIRONMENTAL CHALLENGES PROBLEM SAND MANAGEMENT A CASE STUDY OF JORDAN Researches Review DGTH 47-1 53-70 2018 (July 22, 2020)

Pakhomova, A., Tishkov, S., Shcherbak, A., Karginova-Gubinova, V., \& Alhanaqtah, V. (2019). Potential of energy recovery from biodegradable waste - energy potential and economy. Management Theory and Studies for Rural Business and Infrastructure Development. 41(1), 33-42. doi: https://doi.org/10.15544/mts.2019.04 (July 22, $\underline{2020)}$

Pearce, D. \& Turner, R. (1994). Economics and solid waste management in the developing world. CSERGE working paper WM 1994-05. [Online] Available: https://pdfs.semanticscholar.org/5af7/cb3e126bb123becb2ea055643d7ca5766c40.pdf? ga=2.66612014.1047825 277.1593443716-1988395765.1593443716 (July 22, 2020)

Public Health law No.47 of 2008. [Online] Available: https://untobaccocontrol.org/impldb/wpcontent/uploads/reports/Jordan_annex4 public health_law 2008 En.pdf (July 22, 2020)

Puig Ventosa, I. (2019). The concept of generalized extended producer responsibility (GEPR). [Online] Available: https://www.ecomena.org/generalised-extended-producer-responsibility/ (July 22, 2020)

Rietbergen-McCracken, J., \& Hussein, A. (2000). Economic Instruments for environmental management: a worldwide compendium of case studies. Routledge, $256 \mathrm{p}$.

Russell, C. S. \& Vaughan, W. J. (2003). The choice of pollution control policy instruments in developing countries: Arguments, evidence and suggestions. International Yearbook of Environmental and Resource Economics. Cheltenham: Edward Elgar. [Online] Available: https://pdfs.semanticscholar.org/8217/eb11658f3a92a9f55fd9b730b572edf640fc.pdf (July 22, 2020)

Saidan, M. (2019). Cross-sectional survey of non-hazardous waste composition and quantities in industrial sector and potential recycling in Jordan. Environmental Nanotechnology, Monitoring and Management, 12.

Scharff, H. (2014) Landfill reduction experience in The Netherlands. Waste Management. 34, 2218-2224. doi: 10.1016/j.wasman.2014.05.019 (July 22, 2020)

Selection, Design and Implementation of Economic Instruments in the Solid Waste Management Sector in Kenya: The case of plastic bags [Online] Available: https://wedocs.unep.org/bitstream/handle/20.500.11822/8655/Selection-Design-Implementation-of-EconomicInstruments-Solid-Waste-Management-Kenya.pdf?sequence=3\&amp\%3BisAllowed= (July 22, 2020)

Shatnawi, R. (2018). Solid waste management: Classification and public perception on management options at Applied Science University. Jordan Journal of Civil Engineering, 12(3), 379-388.

The Jordanian Environment Protection Law No. 52 of 2006). [Online] Available: https://www.ilo.org/dyn/natlex/docs/ELECTRONIC/98208/116783/F1925957149/Environmental_Protection_Law No 52 of 2006 en.pdf (July 22, 2020) 
United Nations Environment Program (2005). Solid waste management. [Online] Available: http://www.unep.or.jp/ietc/Publications/spc/Solid Waste_Management/index.asp. (July 22, 2020)

Walls, M. (2013) Deposit-refund systems in practice and theory. In: Shogren, J.F. (ed.) Encyclopedia of energy, natural resource, and environmental economics. Waltham: Elsevier, pp.133-137.

Veronika Alhanaqtah was born in Minsk, Belarus, in 1983. She received her $\mathrm{PhD}$ in Economics from the Belarusian State University in 2010. She was hired as the Lecturer (2008), Assistant Professor (2011) and then as an Associate Professor (2013) at the Department of Theoretical and Institutional Economics at the Belarusian State University. She is currently the Assistant Professor at the College of Business at Tafila Technical University (Jordan). Dr. Alhanaqtah has been given a special award of the President of the Republic of Belarus for talented young scientists (2012). She is the winner of the international competition for the best author's research "Ecology and long-term investments" (Russia, 2018). She worked as the consultant in working out the bills concerning the environmental protection and rational use of natural resources in the Republic of Belarus (2009), the researcher in UNDP-Belarus on implementation of mechanisms of Kyoto Protocol (2006-2009). Since 2019 she is a member of the InterGlobe Research Network. 